\title{
Methionine deficiency and iron retention in the rat*
}

\author{
By NATHAN KAUFMAN, JANIS V. KLAVINS AND THOMAS D. KINNEY \\ Department of Pathology, Duke University Medical Center, \\ Durham, NC, USA
}

(Received ${ }_{25}$ February 1966-Accepted 7 Fune I966)

\begin{abstract}
I. Methionine-deficient diets were given to rats for 4 weeks. 2. This resulted in a decrease in total body iron, due to a decrease either in $\mathrm{Fe}$ absorption or Fe retention. 3. There was inhibition of growth, development of anaemia and a shift of body $\mathrm{Fe}$ to the liver. 4 . There were no histological alterations which could be interpreted as specific to methionine deficiency. 5. These findings were different from reports of effects of ethionine in which there is an increased $\mathrm{Fe}$ absorption and various tissue alterations, including pancreatic acinar and liver damage.
\end{abstract}

Experiments now presented were designed to investigate the effects of methionine deficiency on iron absorption and storage. The pertinent question raised is whether with the methionine deficiency there is an increase in the absorption of $\mathrm{Fe}$, since it is known that ethionine, a metabolic antagonist and analogue of methionine, causes an increase in the absorption of Fe from the gastro-intestinal tract and deposition of large amounts of $\mathrm{Fe}$ in the liver (Kinney, Kaufman \& Klavins, 1955).

\section{EXPERIMENTAL}

Thirty-two rats of the Sprague-Dawley strain, each weighing approximately $\mathrm{I} 80 \mathrm{~g}$, were used in these experiments. The animals were divided into two groups, an experimental and a control. The experimental group was given a synthetic diet in which the casein was replaced by an amino acid mixture having approximately the same amino acid composition as casein, but with the methionine omitted; the methionine was replaced by an equivalent amount of glucose. The control animals were pair-fed and received the same diet, but methionine was not excluded. The composition of the amino acid mixture is listed in Table $\mathrm{I}$. The basal diet consisted of $16.7 \mathrm{I} g$ of amino acid mixture, 68. $19 \mathrm{~g}$ glucose, I I ml maize oil (Mazola oil, made by Best Foods Division, Corn Products Company, New York, NY, USA), and $4 \mathrm{~g}$ of salt mixture which contained I9 ${ }^{\cdot} 3 \mathrm{mg}$ Fe (Hegsted, Mills, Elvehjem \& Hart, I94I). Each $100 \mathrm{~g}$ diet was supplemented with the following vitamins: thiamine chloride, $400 \mu \mathrm{g}$; pyridoxine hydrochloride, $400 \mu \mathrm{g}$; riboflavine, $800 \mu \mathrm{g}$; calcium pantothenate, I $500 \mu \mathrm{g}$; nicotinic acid, $2500 \mu \mathrm{g}$; vitamin A, approximately 60 USP units; vitamin D, I USP unit. Choline chloride was not included in the basal diet in order that this diet should simulate, as far as possible, the composition of the diet in the experiments with ethionine administration (Kinney et,al. 1955). The animals were housed in individual mesh-bottom cages, given water ad lib. and weighed twice a week.

* This work was supported by Public Health Service Grant No. AM 04839 from the National Institute of Arthritis and Metabolic Diseases, National Institutes of Health, USA. 
The experiments lasted for 4 weeks. At the beginning of the experiment haemoglobin and haematocrit values were determined and the animals were paired according to weights and haemoglobin values. When the rats were killed, blood was obtained for haemoglobin and haematocrit determinations. In half of the animals, at the end of the experiment, serum $\mathrm{Fe}$ content and total Fe-binding capacity of serum were determined (Carraway, 1963 ). Livers were weighed and sections fixed in buffered formalin for histological examination, and subsequently stained for fat, with haematoxylin and eosin, and for $\mathrm{Fe}$. The $\mathrm{Fe}$ staining was carried out by using Perls's technique (Perls, I 867) as modified by Gomori (1936). Sections of other organs were examined after haematoxylin and eosin staining.

Table I. Composition of amino acid mixture

\begin{tabular}{lclc}
\multicolumn{1}{c}{ Amino acid } & Weight $(\mathrm{g})$ & \multicolumn{1}{c}{ Amino acid } & Weight $(\mathrm{g})$ \\
L-Cystine & 0.036 & L-Leucine & 2.664 \\
L-Methionine & 0.540 & L-Isoleucine & 0.918 \\
L-Arginine (free base) & 0.684 & L-Glycine & 0.090 \\
L-Histidine & 0.342 & L-Alanine & 0.342 \\
L-Lysine (monohydrochloride) & 1.552 & L-Proline & $1 \cdot 152$ \\
L-Tyrosine & 0.936 & L-Glutamic acid & 3.924 \\
L-Tryptophan & 0.216 & L-Aspartic acid & 0.738 \\
L-Phenylalanine & 0.702 & L-Serine & 0.072 \\
L-Threonine & 0.828 & L-Hydroxyproline & 0.036 \\
L-Valine & 0.936 & & 16.708
\end{tabular}

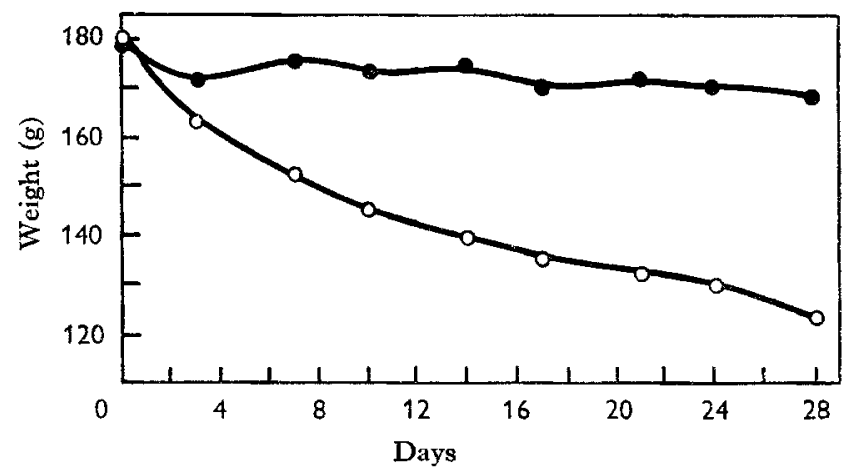

Fig. I. Mean weight change in methionine-deficient rats $(\mathrm{O}-\mathrm{O})$ and pair-fed controls $(\boldsymbol{0}-\boldsymbol{\bullet})$.

The livers and intestinal tracts of the other half of the animals in each group were removed and the remaining carcasses and livers were digested separately in sulphuric, nitric and perchloric acids, and the digest was analysed for Fe (Kitzes, Elvehjem \& Schuette, 1944). The results were analysed statistically by Student's $t$ test for paired comparisons.

\section{RESULTS}

The animals on the methionine-deficient diet lost more weight than the pair-fed controls (Fig. I) and by the end of the experiment their weights were significantly lower (Table 2). The total mean food intake per animal was approximately $215 \mathrm{~g}$. 
Fe values for the total body, excluding intestine, were significantly lower in the methionine-deficient animals than in the controls. Similarly, the carcass Fe values when the liver was not included were also significantly lower. On the other hand, liver Fe values were significantly higher than in the control animals (Table 3). The haemoglobin values increased significantly in both the experimental and the control rats, but in the methionine-deficient group the increase was not as great. In spite of this gain, these values were significantly lower in the experimental than in the control animals by the end of the experiment. There was no statistically significant difference between the initial and final haematocrit values in the methionine-deficient rats. In the control animals the haematocrit values increased significantly, so that by the end of the experiment they were greater than those in the methionine-deficient rats.

Table 2. Body-weight, haematocrit and haemoglobin values in methionine-deficient and pair-fed control rats

\begin{tabular}{|c|c|c|c|c|c|c|c|c|c|c|}
\hline \multicolumn{2}{|l|}{ Animals } & \multicolumn{2}{|c|}{$\begin{array}{l}\text { Mean body- } \\
\text { weight (g) }\end{array}$} & \multirow{2}{*}{$\begin{array}{l}\text { Liver } \\
\text { weight } \\
\text { (g) }\end{array}$} & \multirow{2}{*}{$\begin{array}{l}\text { Kidney } \\
\text { weight* } \\
\text { (g) }\end{array}$} & \multirow{2}{*}{$\begin{array}{l}\text { Spleen } \\
\text { weight* } \\
\text { (g) }\end{array}$} & \multicolumn{2}{|c|}{$\begin{array}{c}\text { Haemoglobin } \\
\text { concentration } \\
(\mathrm{g} / 100 \mathrm{ml})\end{array}$} & \multicolumn{2}{|c|}{ Haematocrit } \\
\hline Condition & No. & Initial & Final & & & & Initial & Final & Initial & Final \\
\hline $\begin{array}{l}\text { Deficient } \\
\text { Control }\end{array}$ & $\begin{array}{l}16 \\
16\end{array}$ & $\begin{array}{l}180 \\
\text { I } 78\end{array}$ & $\begin{array}{l}123 \\
168\end{array}$ & $\begin{array}{l}4.79 \\
4.51\end{array}$ & $\begin{array}{l}I \cdot I O \\
I \cdot I 6\end{array}$ & $\begin{array}{l}0.22 \\
0.33\end{array}$ & $\begin{array}{l}12 \\
12\end{array}$ & $\begin{array}{l}13 \\
16\end{array}$ & $\begin{array}{l}43 \\
44\end{array}$ & $\begin{array}{l}45 \\
52\end{array}$ \\
\hline $\begin{array}{l}\text { SE of difference } \\
P \text { (deficient } v \text {. } \\
\text { controls) }\end{array}$ & & $2 \cdot 4$ & $\begin{aligned} & 4.2 \\
< & 0.01\end{aligned}$ & 0.30 & 0.04 & 0.02 & 0.25 & 0.32 & 1.09 & 0.89 \\
\hline
\end{tabular}

* Eight animals in each group.

Table 3. Iron determinations in methionine-deficient and pair-fed control rats

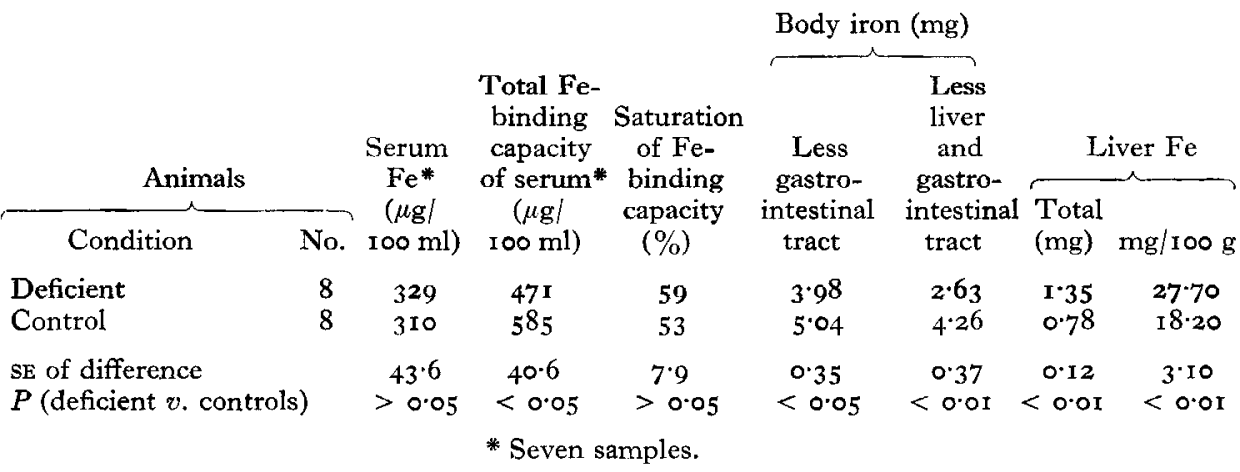

There was a decrease in the total Fe-binding capacity of serum in the methioninedeficient animals, with no significant difference in the serum $\mathrm{Fe}$ content or serum $\mathrm{Fe}$ saturation (Table 3 ).

Liver weights were not significantly different when the experimental and control groups were compared. In the methionine-deficient rats there was centrilobular fatty metamorphosis. There was no liver cell necrosis, bile duct proliferation, or cellular infiltrate. Only occasionally were small amounts of fat seen in the control rats. Histochemically demonstrable $\mathrm{Fe}$ was increased in livers of the methionine-deficient rats 
and it was distributed diffusely. Small amounts of Fe were noted occasionally in control rats, but there was less in the control rat than in the paired methionine-deficient rat.

No histological differences were noted when pancreases of the control and methionine-deficient animals were compared.

The spleen weights were markedly decreased in the animals on methionine-deficient diets (Table 2), but there was no significant difference in kidney weights.

\section{DISCUSSION}

Fe values for total body in the methionine-deficient group were significantly lower than in the pair-fed controls. This clearly indicates that in methionine deficiency there is a decrease in the absorption or retention of Fe. In addition, there was a decrease in the total Fe-binding capacity which could be related to the hypoproteinaemia observed in methionine deficiency (Glynn, Himsworth \& Neuberger, 1945). The increased $\mathrm{Fe}$ content of the liver would indicate an internal shift in $\mathrm{Fe}$ stores and is not a reflection of increased absorption of Fe. This is supported by the fact that an anaemia develops in methionine deficiency in young animals (Glynn et al. 1945) and that in the present experiments, in which older rats were used, the haemoglobin values were also significantly lower. From this it would appear that there is a decrease in haemoglobin synthesis and utilization of the $\mathrm{Fe}$ with deposition of $\mathrm{Fe}$ in the liver. The increase in the liver $\mathrm{Fe}$ values was reflected in the increase in $\mathrm{Fe}$ seen histochemically.

From the present experiments it appears that the Fe kinetics in methionine deficiency differ from those in ethionine feeding. When synthetic diets were supplemented with ethionine for 4 weeks (Kinney et al. 1955), or when Purina chow was supplemented with ethionine for 6 weeks (Klavins, Kinney \& Kaufman, 1965), Fe absorption was increased. There was no anaemia within the 6-week period (Klavins et al. 1965). Whereas in methionine deficiency the increased liver $\mathrm{Fe}$ values are attributed to an internal shift of $\mathrm{Fe}$, in ethionine feeding they are a reflection of increased absorption since the total body $\mathrm{Fe}$ is increased in contrast to the effect in methionine-deficient animals, whose total body $\mathrm{Fe}$ is decreased.

Further differences between the effects of methionine deficiency and ethionine feeding are seen in the anatomical changes. There was extensive pancreatic acinar damage and liver damage with ethionine; these changes were not seen with methionine deficiency. The only significant alterations were in the liver, where there was centrilobular fatty metamorphosis.

The pattern of weight changes is also different in methionine deficiency and in ethionine feeding. In methionine deficiency there was a steady continuous decline in weight (Fig. I), whereas in ethionine feeding there was an initial rapid weight loss followed by a slow weight gain (Klavins, Kinney \& Kaufman, 1959; Kinney, Kaufman, Klavins, Marsters \& Tseng, I960). From this it appears that the effects of ethionine cannot be altogether explained by methionine deficiency due to the action of ethionine, in spite of the fact that almost all of the ethionine effects can be prevented or diminished by simultaneous administration of methionine (De Monterice, Kaufman, Kinney \& Klavins, 196r; Simpson, Farber \& Tarver, 1950; Farber \& Corban, 1958; Artom, 
1959; Stekol \& Weiss, 1949; Lee \& Williams, 1952; Conney, Miller \& Miller, 1956, 1957; Freedland \& Harper, 1958; Farber \& Popper, 1950; Jensen, Chaikoff \& Tarver, 1951; Koch-Weser \& Popper, 1952; Farber \& Ichinose, 1957).

\section{REFERENCES}

Artom, C. (1959). F. biol. Chem. 234, 2259.

Carraway, W. T. (1963). Clin. Chem. 9, I 88.

Conney, A. H., Miller, E. C. \& Miller, J. A. (1956). Cancer Res. I6, 350.

Conney, A. H., Miller, E. C. \& Miller, J. A. (1957). ₹. biol. Chem. 228, 753 .

De Monterice, B., Kaufman, N., Kinney, T. D. \& Klavins, J. V. (1961). Archs Path. 72, 550.

Farber, E. \& Corban, M. S. (1958). F. biol. Chem. 233, 625.

Farber, E. \& Ichinose, H. (1957). Proc. Am. Ass. Cancer Res. 2, 199.

Farber, E. \& Popper, H. (I950). Proc. Soc. exp. Biol. Med. 74, 838 .

Freedland, R. A. \& Harper, A. E. (1958). F. biol. Chem. 233, 1041.

Glynn, L. E., Himsworth, H. P. \& Neuberger, A. (1945). Br. F. exp. Path. 26, 326.

Gomori, G. (1936). Am. F. Path. 12, 655.

Hegsted, D. M., Mills, R. C., Elvehjem, C. A. \& Hart, E. B. (194I). F. biol. Chem. 138, 459.

Jensen, D., Chaikoff, I. L. \& Tarver, H. (r95I). Y. biol. Chem. r92, 395.

Kinney, T. D., Kaufman, N. \& Klavins, J. V. (1955). F. exp. Med. 102, 15 I.

Kinney, T. D., Kaufman, N., Klavins, J. V., Marsters, R. W. \& Tseng, C. Y. (I960). Am. F. Path. 37, 137 .

Kitzes, G., Elvehjem, C. A. \& Schuette, H. A. (1944). F. biol. Chem. 155, 653.

Klavins, J. V., Kinney, T. D. \& Kaufman, N. (1959). $\mathscr{F} . ~ N u t r . ~ 67,363$.

Klavins, J. V., Kinney, T. D. \& Kaufman, N. (I965). Am. F. Path. 46, 969.

Koch-Weser, D. \& Popper, H. (1952). Proc, Soc. exp. Biol. Med. 79, 34.

Lee, N. D. \& Williams, R. H. (1952). Biochim. biophys. Acta 9, 698.

Perls, M. (1867). Virchozos Arch. path. Anat. Physiol. 39, 42.

Simpson, M. V., Farber, E. \& Tarver, H. (1950). F. biol. Chem. I82, 8r.

Stekol, J. A. \& Weiss, K. (1949). F. biol. Chem. 179, 1049. 